\title{
Application of Foreign Law in Economic Disputes and Implementation of National Interests
}

\author{
N.V. Deltsova ${ }^{1}$, U.A. Dorofeeva ${ }^{1}$, M.N. Zubkova ${ }^{1}$, and M.A. Tokmakov ${ }^{1, *}$ \\ *Corresponding author: maxim.tokmakov@gmail.com. \\ ${ }^{1}$ Samara State University of Economics. Samara, Russia
}

\begin{abstract}
In the context of globalization, the question of protecting one's own national interests is becoming more acute for the state on whose territory foreign law and order is applied. The application of foreign legislation in economic disputes creates various problems and raises questions related to the establishment of the content of foreign law, which must be resolved in the context of Theoretical understanding and law enforcement practice. This study is aimed at identifying the risks of uncertainty in the application of foreign law to relations involving a foreign element in the Russian legal reality and finding ways to overcome them taking into account national interests. Special attention is paid to consideration of the Institute of non-use (limitations) of foreign law is presented in the form of rules on the application of the mandatory rules of the forum (lex fori), the reservation of public order (order public), and eliminating the use of foreign law in case of conflict.
\end{abstract}

Keywords: national interest, foreign law, lex fori, agreement on applicable law, conflict of qualifications, public order.

\section{Introduction}

Modern socio-economic integration processes and the blurring of national borders in the information environment of the Internet lead to a close interaction of States in the establishment of regulation of relations arising between entities with different nationalities. At the same time, in the conditions of globalization the questions of protection of own national interests become more acute. At the same time, it should be noted that the main meaning of this term is, first of all, the unity of interests of citizens and society of a certain state, and not the interests of any particular ethnic group-the unity of interests in this case is the result of consensus in the basic, indigenous, interests of all citizens of the state. In other words, sharing V. D. Zorkin's position, national interests consist in inviolability of a constitutional system, sovereignty and territorial integrity, in political, economic and social stability, and also in unconditional ensuring legality and maintenance of a law and order, in development of equal and mutually beneficial international cooperation [1].

At present, economic national security is becoming as important as military security and forms the basis of state sovereignty. Given the breadth and diversity of economic relations, understanding the content of enforceable legal norms is often a difficult task. The variety of regulations, prohibitions, restrictions and requirements creates the need not only to form a common concept of the system of legal institutions defined by the national legal order, but also their relationship and interaction. The solution of the problem of collision, conflict of legal norms is not particularly difficult: the rule of hierarchy of legal norms (the ratio of General and private legal norms), as well as the provisions of judicial practice and legal doctrine, which allow to resolve the issue that arose in the process of application of national legislation, helps to solve this problem. At the same time, practicing lawyers, as well as the actual participants of economic relations, are often faced with the problems of applying the rules of foreign law and order and determining their content.

The application of foreign legislation in relations complicated by a foreign element creates various problems and raises questions related to the establishment of the content of foreign law, which must be resolved in the context of theoretical understanding and law enforcement practice. For a state in whose territory a foreign legal order is applied, it is important to balance the observance of national interests and the interests of foreign States. Such a balance is necessary due to the presence of international relations between persons of different States, the presence of each state's obligation to protect the rights and interests of its own citizens and organizations. The present research addresses issues of uncertainty, application of foreign law to particular relationships, as well as problems of application of conflict rules arising in connection with the operation of peremptory norms, a conflict of qualifications categories of Russian and foreign law and public order, taking into account national interests.

In connection with the above, the following issues are to be resolved within the framework of this study:

- how big are the risks arising from the uncertainty of the application of foreign law to relations involving a foreign element for the subjects of such relations?

- whether adequate and reasonable are such means of protecting national interests as restriction of foreign norms established in the form of reservation of public order, the application of mandatory rules and elimination of the use of foreign law in case of conflict of qualifications?

The purpose of this study is to identify risk uncertainty of application of foreign law to the relations within the form of participation of foreign element in the Russian legal reality and finding ways to overcome them, taking into account national interests, as well as to consider the Institute of non-application of foreign law presented in the form of rules on 
the application of the mandatory rules of the forum (lex fori), the reservation of public order (order public), and eliminating the use of foreign law in case of conflict of qualifications as a legal means of protecting national interests.

\section{Methods}

The study analyzed the current Russian legislation, Russian law enforcement practice, as well as the provisions of the Russian and foreign legal doctrine, which allowed to identify the main risks associated with the uncertainty of the application of foreign law in the territory of the Russian Federation, and to establish the main directions of overcoming them, taking into account national interests. The paper also considers and summarizes the main elements that make up the institution of non-application (restriction) of foreign law in the Russian legal order, resulting in the conclusion that it is necessary to find a balance between national interests and the interests of foreign States when using this institution.

\section{Results}

\subsection{Uncertainty of application of foreign law}

Uncertainty for each of the parties in the question whether this or that rule to be applied to the dispute in case of its occurrence can significantly complicate the achievement of the economic goal of the party participating in foreign economic turnover. According to J. Basedow, the application of foreign law is not a matter of tolerance towards a foreign state, but rather respect for the expectations of individuals that their relations will be governed by the laws of a particular foreign jurisdiction [2]. Unfortunately, the complete elimination of legal uncertainty in this matter is impossible, since the application of conflict rules depends on the law of the forum (lex fori), i.e. the procedural law of the state where a dispute involving foreign element shall be considered on the merits.

An equally complex situation associated with the uncertainty of the application of foreign law arises when a national conflict of laws rule prescribes the application of foreign law, and this foreign law (its conflict of laws rule) indicates the application of the national law, i.e. refers back (renvoi), or a similar reference is made to the law of a third state [3].

Agreement on applicable law

The possibility of a Russian court applying a foreign legal norm always causes certain risks associated with a variety of circumstances. The economic entities involved in the dispute do not always understand the rules of which state are designed to settle the dispute between them. To some extent, the agreement on the applicable law helps to resolve this issue. A. J. Belohlavek notes that the parties can at any time agree on the applicable law, including during the trial, and such an agreement may differ from the original agreement concluded before the proceedings [4]. Similar rules are provided by the Russian legislation (article 1210 of the Civil Code of the Russian Federation [5]).

At the same time, according to article 249 of the Arbitration Procedure Code of the Russian Federation, if the parties have entered into an agreement in which they have determined that the Russian arbitration court has competence to consider a dispute related to their entrepreneurial and other economic activities, the Russian court will have exclusive competence to consider the dispute, provided that such an agreement does not change the exclusive competence of a foreign court [6].

Nevertheless, the choice of law agreement does not definitively remove doubts as to both the legal system chosen by the court as competent in resolving the dispute and the directly applicable legal rules, including in the case of a plurality of legal systems operating in the territory of the state whose law is applicable to the disputed relations or its individual components.

\subsection{Protection of national interests by non-application of foreign law}

\section{Application of the peremptory norm}

The establishment of the content of a foreign law is preceded by the stage of establishing the presence or absence of grounds for blocking the application of a conflict of laws rule. One of the grounds for refusal to apply foreign law is the effect of a peremptory norm of the law of the country of the court. The validity of recourse to mandatory rules and refusal in this regard from the application of foreign law is illustrated by M. P. Shestakova on the following example. The parties choose as applicable law of the state whose law sets the Statute of limitations for filing claims that is different from the period prescribed by the mandatory rule of a state, which is associated with all of the substantive relations of the parties circumstances. In order to prevent circumvention of the law, in many legal orders there is a provision according to which in such situations the rules chosen by the parties are not applied by virtue of a peremptory norm. That is, in this case, the rule on the limitation period of the country with which the relationship has arisen is subject to application [7]

The conflict of qualifications

The norms of foreign law are also inapplicable if the categorical apparatus of national legislation and the legal system of a foreign state contradict each other, i.e. there is a conflict of qualifications. To illustrate the need to eliminate the conflict of qualifications, one can cite the following example: the institution of trust existing in common law 
countries is absent in continental law countries, including Russia, its qualification is necessary to establish the content and application of this concept.

The resolution of this conflict in Russian law is carried out by a unilateral conflict of law rule linking the disputed legal relationship to Russian law. Article 1187 of the Civil Code of the Russian Federation establishes the following rule: in determining the law to be applied, the interpretation of legal concepts is carried out in accordance with Russian law, unless otherwise provided by law [5].

The newest interpretation of the concept of a conflict of qualifications is carried out by the Supreme Court of the Russian Federation, which clarified that the rule established in the Civil Code of the Russian Federation represents the primary qualification of a legal norm, since the interpretation of legal concepts is carried out precisely for the purpose of determining the applicable conflict of law norm. After determining the applicable law on the basis of the relevant conflict of law norms, the court interprets the applicable norms of foreign law, guided by the provisions of Article 1191 of the Civil Code of the Russian Federation on the establishment of the content of foreign law [8]

\section{Public Order}

In this study, S. Brekoulakis concludes that a state can prohibit any arbitration in its territory, the subject of which is not amenable to arbitration, that is, it contradicts the public order of that particular state [9]. The need for such a rule as a reservation on public order (order public) is undeniable. Of course, there are provisions in the norms of national legislation, the observance of which is objectively necessary, despite the legal system chosen by the court for application in accordance with the conflict of laws norm.

A reservation on public order (order public) is applied in Russian civil law in case of refusal to enforce a foreign judicial or arbitral award, refusal to execute an order of a foreign court or competent authority of a foreign state. It is worth noting that the Supreme Court of the Russian Federation warned the courts against the unreasonable use of ordre public in cases complicated by a foreign element, indicating that the court does not apply the rule of foreign law only in exceptional cases when the consequences of applying such a foreign rule are clearly contrary to the public order of Russia. In addition, the absence of rules or legal institutions in Russian law that are similar to the rules or legal institutions of applicable foreign law is not in itself a basis for the application of ordre public [8]. Thus, in the framework of case No. A60-308/2018, Russian courts, applying the rule of foreign law, noted that the absence in Russian legislation of a rule similar to paragraph $b$ of $\S 201$ of the US Copyright Law [10] does not mean that the ownership of the author's title should be determined based on the norms of Russian law.

Substantive and procedural law

It is also worth considering that even in cases where foreign law is applicable to resolve the dispute on the merits, the court in considering the dispute is guided by national procedural legislation. As A. Surana points out, local substantive legislation may be repealed in specific cases, and foreign law will apply instead. However, local procedural law, as a rule, cannot be violated by foreign law, since the local judicial authority will only apply its own procedural rules (procedural rules of the forum). Accordingly, both internal affairs and affairs with foreign elements are regulated by local procedural legislation [11]. A similar rule is provided for by Russian law - cases involving foreign persons are considered by the arbitration court in accordance with the rules of the Arbitration Procedure Code of the Russian Federation.

\section{Conclusion}

Each state is interested in the legal certainty provided to the subjects of the civil turnover, in the evidence of the actions taken in the process of carrying out economic activities. Any uncertainty, including that associated with the application of foreign law in the territory of a state, undermines the stability of economic relations and negatively affects their participants. One of the mechanisms to overcome this uncertainty is the agreement of the parties on the applicable law. At the same time, for the state in whose territory the foreign legal order is applied, the observance of one's own national interests, achieved through the application of the law of the country of the court (lex fori) and the non-application of foreign law, is of particular importance. However, it is also obvious that the widespread and unjustified use of restrictions on the use of foreign law and order can lead not to the stability but to a violation of the principle of mutual courtesy, which impedes the implementation of international treaties and agreements aimed at fulfilling obligations by member states to grant foreign citizens regime less favorable than for their own citizens, which is why when applying foreign law, it is so important to find a balance of national interests and interests of foreign States.

\section{References}

1. V.D. Zorkin, The role of law in ensuring national interests. Law and Security, 1-2 (18-19) (2006). [in Rus.].

2. J. Basedow, The application of foreign law - comparative remarks on the practical side of private international law. In J. Basedow, and K. B. Pißler (Eds.), Private International Law in Mainland China, Taiwan and Europe (pp. 8597). Tübingen: Mohr Siebeck. (2014). 
3. A.A. Khan, A. Ghani, F. ur Rehman, M. Ullah, What is renvoi'? Distinguish the theory of 'single renvoi' from 'double renvoi' with reference to relevant case law in private of international law (2018). URL: https://ssrn.com/abstract=3124439. Accessed: 16.09.2019.

4. A.J. Belohlavek, Substantive law applicable to the merits in arbitration. Romanian Review of Arbitration, 8(2 (30)), $1-16(2014)$

5. Civil Code of the Russian Federation (1994). URL: http://www.consultant.ru/document/cons doc_LAW 5142/. Accessed: 16.09.2019. [in Rus.].

6. Arbitration Procedure Code of the Russian Federation (2002). URL: http://www.consultant.ru/document/cons doc LAW 37800/. Accessed: 16.09.2019. [in Rus.].

7. M.P. Shestakova, Obligations arising from unjust enrichment in private international law. In I.O. Khlestova (Ed), Non-contractual obligations in private international law. Institute of Legislation and Comparative Law under the Government of the Russian Federation (pp. 80-95). Moscow: Norma, INFRA-M (2017). [in Rus.].

8. Resolution of the Plenum of the Supreme Court of the Russian Federation of 09.07.2019 No. 24 "On the application of international private law by the courts of the Russian Federation" (2019). URL: https://rg.ru/2019/07/17/vsdok.html. Accessed: 16.09.2019. [in Rus.].

9. S. Brekoulakis, Law applicable to arbitrability: Revisiting the revisited lex fori. In L. Mistelis, S. Brekoulakis (Eds.), Arbitrability: The international and comparative perspectives. Queen Mary School of Law Legal Studies Research Paper, 21, (pp. 99- 119). London: Kluwer (2009).

10. US Copyright Law. URL: https://www.copyright.gov/title17/. Accessed: 16.09.2019.

11. A. Surana, International civil procedure and principle of 'lex fori' (2006). URL: https://ssrn.com/abstract=915923. Accessed: 16.09.2019. 